Tersedia online di: http://ejournal-balitbang.kkp.go.id/index.php/ma

\title{
PERFORMANSI INSTALASI PENGOLAH AIR LIMBAH TAMBAK SUPERINTENSIF
}

\author{
Rachman Syah\#, Mat Fahrur, Hidayat Suryanto Suwoyo, dan Makmur
}

Balai Riset Perikanan Budidaya Air Payau dan Penyuluhan Perikanan

(Naskah diterima: 25 Oktober 2017; Revisi final: 10 November 2017; Disetujui publikasi: 10 November 2017)

\begin{abstract}
ABSTRAK
Pengolahan air buangan tambak superintensif (TSI) adalah usaha untuk mengurangi beban bahan pencemar yang terkandung di dalam air buangan TSI sehingga aman dan tidak membahayakan saat dibuang ke lingkungan. Penelitian ini bertujuan untuk mengevaluasi desain dan performansi Instalasi Pengolahan Air Limbah (IPAL) dalam memperbaiki kualitas air buangan TSI sebelum dibuang ke badan air. IPAL terdiri atas kolam sedimentasi, dua kolam aerasi, dan satu kolam penampungan. Ke dal am kolam penampungan ditebari ikan mujair serta rumput laut Gracilaria sp. yang dibudidayakan dengan metode long line, berfungsi sebagai biokontrol. Sampel air diambil di bagian inlet IPAL, oulet kolam sedimentasi atau inlet kolam aerasi-1, outlet kolam aerasi-1 atau inlet kolam aerasi-2, outlet kolam aerasi-2 atau inlet kolam penampungan, serta outlet kolam penampungan, setiap dua minggu selama 105 hari pemeliharaan. Parameter yang diukur adalah total padatan tersuspensi (TSS), total amonia nitrogen (TAN), nitrit, nitrat, fosfat, bahan organik terlarut (BOT), dan biological oxygen demand $\left(\mathrm{BOD}_{-5}\right)$. Spesifikasi teknis IPAL yang diamati meliputi ukuran dan volume IPAL, volume dan waktu tinggal air buangan tambak, dan efisiensi kinerja IPAL, serta rasio volume IPAL dan volume total air tambak. Hasil penelitian menunjukkan bahwa IPAL dapat mengurangi beban bahan pencemar dengan tingkat efisiensi antara 53,1\%99,4\% namun masih diperlukan peningkatan kapasitas dalam mengurangi konsentrasi BOT. IPAL menghasilkan efisiensi yang tinggi terhadap TSS, TAN, nitrit, Total Nitrogen (TN), dan fosfat. Rasio volume IPAL dan volume air tambak 30:70 dengan waktu tinggal minimal lima hari, dapat dijadikan acuan dalam pembangunan IPAL tambak superintensif.
\end{abstract}

\section{KATA KUNCl: tambak superintensif; udang vaname; air buangan tambak; instalasi pengolah air limbah (IPAL)}

ABSTRACT: The performance of wastewater treatment plant in superintensive Litopenaeus vannamei shrimp aquaculture. By: Rachman Syah, Mat Fahrur, Hidayat Suryanto Suwoyo, and Makmur

\begin{abstract}
A wastewater treatment plant (WTP) in a super-intensive shrimp farm is used to reduce organic matters contained in super-intensive shrimp farm effluent. Through the WTP, the waste water from shrimp facilities can safely and harmlessly be released to the receiving environments. The aims of this study were to evaluate the design and performance of a WTP in reconditioning waste water released from a super-intensive shrimp farm prior to release to water bodies. The WTP was made of a series of sedimentation pond, two aeration ponds, and one reservoir or equalitation pond. The tilapia fish and seaweed, Gracilaria sp., were stocked in the equalitation pond where the seaweed was cultured using long line method; these organisms were used as bio-control. Water samples were collected fortnightly during 105 days of culturing duration from the WTP inlet, outlet of sedimentation pond or at inlet of the first aeration pond; outlet of the first aeration pond or inlet of the second aeration pond, outlet of the second aeration pond or inlet of equalitation pond and the outlet of equalitation pond. The measured variables were total suspended solid (TSS), total ammonia nitrogen (TAN), nitrite, nitrate, phosphate, total organic matters (TOM ), and five days biological oxygen demand (BOD5). The evaluated technical performances of the plant were its size and volume; volume and retention time of effluent, efficiency of W TP performance and volume ratios of theWTP and total volume of shrimp pond. The results of the study indicated that the WTP was able to reduce concentrations of nutrients and solids in effluent by $53.1 \% 99.4 \%$ of efficiency. However, its capacity need to be increased due to reducing concentrations of TOM. The WTP was highly efficient in reducing the concentrations of TSS, TAN, nitrite, total $\mathrm{N}$, and phosphate. The volume ratios between the plant and pond waters were 30:70 with minimum retention time five which days could be proposed for wastewater treatment pond for super-intensiveshrimp ponds.
\end{abstract}

\section{KEYWORDS: superintensive pond; vanname shrimp; effluent pond; wastewater treatment plant}

\footnotetext{
\# Korespondensi: Balai Riset Perikanan Budidaya Air Payau dan

Penyuluhan Perikanan. Jl. Makmur Dg. Sitakka No.129, Maros

90512, Sulawesi Selatan, Indonesia.

Tel.: + 62411371544

E-mail: rachman222000@yahoo.com
} 


\section{PENDAHULUAN}

Teknologi tambak superintensif (TSI) mulai berkembang untuk udang vaname dengan padat penebaran mencapai $1.250 \mathrm{ekor} / \mathrm{m}^{2}$ dan menghasilkan produktivitas 12,6 ton $/ 1.000 \mathrm{~m}^{2}$ (Syah et al., 2017), bahkan Atjo (2014) mendapatkan 15,3 ton/1.000 m² pada penebaran $720 \mathrm{ekor} / \mathrm{m}^{2}$. Padat penebaran tinggi memberikan konsekuensi terhadap beban limbah yang dihasilkan, disebabkan retensi nitrogen (N) dan fosfor (P) pakan pada budidaya udang vaname, masing-masing adalah $22,27 \%$ dan $9,79 \%$ sehingga nutrien yang terbuang ke lingkungan perairan tambak masingmasing mencapai $77,73 \%$ nitrogen dan $90,21 \%$ fosfor (Hongsheng et al., 2008). Preston et al. (2001) mendapatkan nilai retensi $\mathrm{N}$ pada budidaya udang hanya $22 \%$ sisanya terbuang ke lingkungan. Budidaya udang vaname dengan padat penebaran $50 \mathrm{ekor} / \mathrm{m}^{2}$ menghasilkan beban limbah yang terbuang ke lingkungan perairan mencapai 108,49 $\pm 1,53 \mathrm{kgN}$ dan $56,13 \pm 6,56 \mathrm{kgP}$ (Syah et al., 2006). Pada padat penebaran 500 dan $600 \mathrm{ekor} / \mathrm{m}^{2}$, retensi $\mathrm{N}$ masingmasing 30,47\% dan 33,34\% serta retensi $P$ masingmasing $16,59 \%$ dan $18,05 \%$ sehingga beban limbah N dan $\mathrm{P}$ yang dihasilkan selama proses budidaya dapat mencapai $406,57 \mathrm{kgN}$ dan 100,33 kgP (500 ekor/m²) serta $532,30 \mathrm{kgN}$ dan $119,50 \mathrm{kgP}$ pada padat penebaran 600 ekor/m² (Syah et al., 2014).

Permasalahan utama dalam air buangan TSI adalah tingginya partikel bahan organik, terdiri atas feses udang, pakan yang tidak termakan, karapak udang, serta plankton mati yang mengendap di dasar tambak, serta tingginya kandungan $\mathrm{N}$ dan $\mathrm{P}$ yang dapat meningkatkan kesuburan perairan. Pada tambak superintensif dengan padat penebaran 750-1.250 ekor/ $\mathrm{m}^{2}$, sedimen yang terbentuk dapat mencapai 18,2-21,9 ton/0,1 ha/siklus produksi udang (Suwoyo et al., 2015). Preston et al. (2001) menyatakan bahwa lumpur yang terbentuk selama proses budidaya dapat mencapai 35-60 t/ha/siklus produksi udang. Meningkatnya limbah padat dalam sistem budidaya harus dicegah karena dapat menyebabkan penurunan oksigen terlarut dan meningkatkan kadar amonia akibat adanya proses dekomposisi bahan organik yang bersifat toksik bagi komoditas budidaya. Oleh karena itu, pembuangan lumpur yang terbentuk perlu dilakukan secara periodik.

Air buangan tambak udang superintensif dengan padat penebaran 750-1.250 ekor $/ \mathrm{m}^{2}$ mengandung rataan total suspended solid (TSS) 798-924 mg/L, bahan organik terlarut (BOT) 81,227-88,641 mg/L; total nitrogen (TN) 9,8389-14,4260 mg/L; dan total fosfat (TP) 7,8770-11,8720 mg/L (Fahrur et al., 2015). Nilai tersebut telah melebihi batas ambang dari standar air buangan tambak yang diperkenankan sehingga berpotensi memberikan dampak negatif terhadap kualitas lingkungan badan air penerima beban limbah. Sementara intensitas dampak tergantung pada sistem budidaya, jenis komoditas, manajemen air (jumlah dan frekuensi pergantian), padat penebaran yang diaplikasikan, jumlah dan mutu pakan yang digunakan, profil pantai dan karakteristik perairan pantai. Karakterisasi air buangan tambak menjadi prasyarat dalam menentukan daya dukung perairan untuk pengembangan tambak (Teichert-Coddington et al., 1995; Tookwinas, 1988). Berdasarkan potensi beban limbah dan dampaknya, maka aplikasi Instalasi Pengolah Air Limbah (IPAL) sebagai bagian dari sistem budidaya harus dilakukan.

Upaya pengolahan air buangan tambak udang intensif telah dikembangkan dengan menggunakan sistem resirkulasi (Castine et al., 2013; Hochheimer, 2003), kolam sedimentasi dan penggunaan kembali air buangan, serta mengkonstruksi lahan basah (Anh et al., 2010), sistem lahan basah buatan aliran air permukaan yang ditanami rumput vetiver, Chrysopogon zizanioides, L. (Rahardjo et al., 2015), pemanfaatan kekerangan, Crassostrea lugubris dan kerang hijau, Perna viridis, serta rumput laut Gracilaria fisheri untuk memperbaiki kualitas air buangan tambak udang (Songsangjinda, 2004), filtrasi oleh bivalve, Saccostrea commercialis (Jones et al., 2001), oyster, Cassostrea rhizophore (de Azevedo et al., 2015), lumut Enteromorfa flexuosa dan rumput laut, Gracilaria verrucosa (Devi \& Gowri, 2007) atau melalui aplikasi teknologi bioflok (Crab et al., 2007; Krummenauer et al., 2014), serta penggunaan filter (Jegatheesan et al., 2006) dan teknik bioremediasi (Divya et al., 2015). Sebagian besar penelitian tersebut masih dalam skala laboratorium sehingga perlu ditingkatkan kapasitasnya untuk skala komersial.

IPAL-TSI dikembangkan dengan mengacu pada permasalahan air buangan TSI yaitu kandungan TSS, TN, TP, BOT, dan Biological Oxygen Demand (BOD) yang tinggi, serta rendahnya $\mathrm{pH}$ dan oksigen terlarut (DO). Dari kajian awal IPAL-TSI memberikan informasi bahwa parameter TSS, pH, DO, BOD, dan BOT air buangan tambak dapat diturunkan sampai batas ambang yang dipersyaratkan bagi air buangan tambak. Sementara parameter TN dan TP belum mencapai batas ambang yang dipersyaratkan (Fahrur et al., 2016). Penelitian ini bertujuan untuk mengevaluasi desain dan performansi IPAL pada budidaya udang vaname superintensif, untuk memperoleh informasi tentang efektivitas IPAL, rasio volume antara IPAL dan air buangan TSI, dan waktu tinggal air buangan tambak di IPAL. Informasi ini memberikan kontribusi terhadap 
peran IPAL untuk mendukung aspek manajemen budidaya udang vaname superintensif yang efektif dan efisien serta berkelanjutan dan pada gilirannya dapat meningkatkan produksi udang tanpa merusak lingkungan.

\section{BAHAN DAN METODE}

Satu unit IPAL dengan total volume sekitar 7.000 $\mathrm{m}^{3}$, dibagi menjadi empat kolam. Kolam pertama berfungsi sebagai kolam sedimentasi, kolam kedua dan ketiga sebagai kolam aerasi, dan kolam keempat sebagai kolam penampungan atau ekualisasi sekaligus sebagai kolam bioindikator kelayakan habitat bagi organisme budidaya (Gambar 1). Evaluasi kinerja IPAL dilakukan dengan mengkaji aspek (1) desain wadah terkait dengan ukuran dan volume atau daya tampung limbah masing-masing petak, (2) waktu tinggal air buangan dalam IPAL, dan (3) efektivitas kinerja IPAL. Pada kolam penampungan ditebar rumput laut Gracilaria sp. dan ikan mujair sebagai bioindikator kelayakan air buangan TSI yang diduga tel ah memenuhi syarat untuk dialirkan atau dibuang ke lingkungan perairan (Gambar 1b). Berdasarkan kinerja IPAL diharapkan dapat ditentukan rasio antara volume IPAL dan total volume air budidaya udang.

Parameter utama yang diukur meliputi TAN, nitrit, nitrat, fosfat, TSS, BOT, dan BOD ${ }_{-5}$. Pengambilan sampel selama satu siklus produksi, dilakukan setiap dua minggu pada posisi inlet IPAL, outlet kolam pengendapan atau inlet kolam aerasi-1, outlet kolam aerasi-1 atau inlet kolam aerasi-2, outlet kolam aerasi-2 atau inlet kolam ekualisasi, dan outlet kolam ekualisasi atau outlet IPAL sebelum dibuang ke laut.

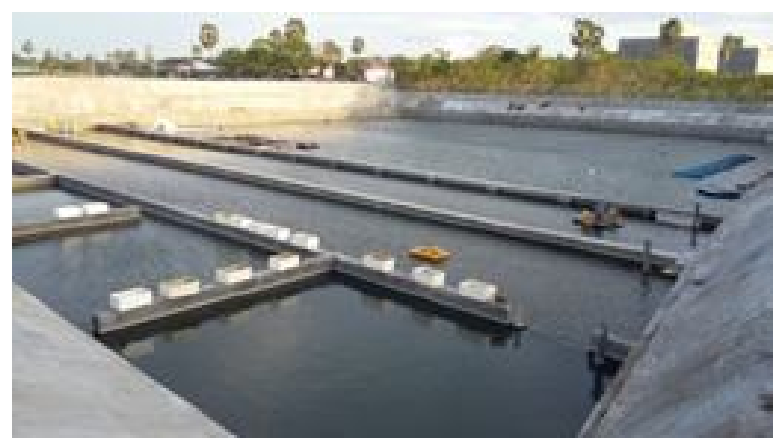

A
Efektivitas IPAL dihitung dengan membandingkan selisih nilai parameter kualitas air di inlet dan outlet dibagi dengan nilai parameter kualitas air di inlet.

$$
\text { Efisiensi IPAL }(\%)=(A-B) / A \times 100
$$

di mana: A: Nilai parameter influent (inlet)

B: Nilai parameter effluent (outlet)

Tingkat efisiensi IPAL dikategorikan mengacu pendapat Tchobanoglous et al. (1991), sebagai berikut: Sangat efisien: $x>80 \%$ efisien: $60 \%<x=80 \%$ cukup efisien: $40 \%<x=60 \%$ kurang efisien: $20 \%<x=$ $40 \%$ tidak efisien: $x=<20 \%$

\section{HASIL DAN BAHASAN}

\section{Desain IPAL Tambak Superintensif}

Konstruksi bangunan IPAL didesain berdasarkan karakteristik air buangan tambak superintensif, jumlah petak tambak superintensif yang beroperasi, dan perkiraan volume air buangan yang dikeluarkan setiap hari, serta waktu tinggal air buangan dalam IPAL. Kinerja IPAL-TSI ditentukan oleh seberapa jauh unit pengolahan dapat berfungsi memperbaiki karakteristik air buangan TSI mendekati prasyarat standar yang ditentukan.

Kolam sedimentasi merupakan pengolahan tahap pertama secara fisik untuk mengurangi kandungan padatan tersuspensi melalui proses pengendapan dan didesain dalam bentuk enam kolam bersekat-sekat agar terjadi pelambatan arus air buangan dan memperpanjang jalur atau waktu alir sehingga memacu proses pengendapan partikel padat. Pada kolam ini,

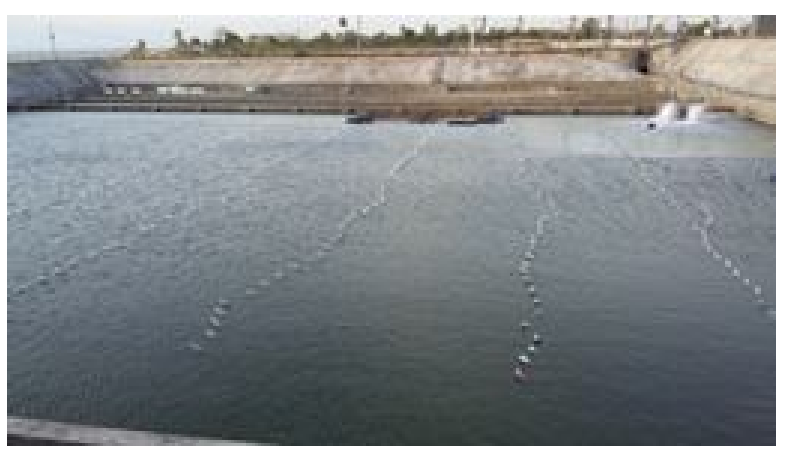

B

Gambar 1. Instalasi pengolah air limbah (IPAL) tambak superintensif (A) dan kolam ekualisasi yang ditanami rumput laut (B).

Figure 1. Watewater treatment plant (WTP) of superintensive pond (A) and equalitation pond which is cultivated with seaweed $(B)$. 
air buangan mulai mengalami proses pengendapan dimana partikel-partikel padat dibiarkan mengendap, sedangkan partikel-partikel yang ringan akan mengapung membentuk busa.

Kolam aerasi pada dasarnya merupakan unit pengolahan limbah yang dilengkapi sistem aerasi, bertujuan untuk meningkatkan kadar oksigen terlarut, menurunkan BOD, dan menaikan pH dalam air buangan, serta membuang $\mathrm{CO}_{2}$ dan $\mathrm{H}_{2} \mathrm{~S}$, serta gas-gas terlarut lainnya. Kolam aerasi terdiri atas dua kolam dan didesain agar mampu mengoksidasi materi organik yang dilakukan oleh bakteri aerob, serta nitrifikasi nitrogen.

Kolam ekualisasi merupakan kolam penampungan air buangan dalam tahap akhir, dimana seluruh air buangan yang sudah diolah dialirkan dan ditampung di kolam ekualisasi. Pada kolam ekualisasi dipelihara rumput laut Gracilaria sp. dan ikan mujair yang berfungsi sebagai bioindikator. Rumput laut akan menyerap nutrien dan mengonversi ke dalam biomassa yang dapat dipanen. Sementara nutrien yang tersisa akan memicu perkembangan populasi plankton sebagai pakan alami bagi ikan mujair. Kolam ekualisasi juga berfungsi untuk mengetahui secara cepat apakah air hasil olahan IPAL cukup layak bagi organisme hidup. Jika ikan yang ada di dalam kolam ekualisasi dapat hidup dengan normal berarti air olahan IPAL layak bagi kehidupan organisme perairan dan dikategorikan baik. Sebal iknya, jika ikan mengalami kematian maka berarti air olahan IPAL masih dikategorikan buruk.

Total luas dan volume tampung bangunan IPAL-TSI masing-masing adalah $5.451 \mathrm{~m}^{2}$ atau $6.987 \mathrm{~m}^{3}$ (Tabel 1). Berdasarkan standar pedoman teknis untuk kelayakan struktur bangunan, maka IPAL-TSI dapat dinyatakan telah memenuhi standar teknis yang terkait dengan persyaratan dari segi keamanan dan keselamatan terhadap lingkungan dan pengguna bangunan IPAL.

Ditinjau dari efektivitas kerja, maka kolam sedimentasi perlu dilengkapi dengan al at bantu pompa lumpur portableuntuk memudahkan dalam operasional pengurasan kolam sedimentasi. Berdasarkan ketebalan sedimen di dalam kolam sedimentasi sangat berpengaruh terhadap efektivitas proses sedimentasi yang terjadi. Pemindahan sedimen disarankan perlu dilakukan dari kolam sedimentasi (pemompaan sludge/ lumpur) manakala ketebalan sedimen telah mencapai $50 \%$ dari kedalaman kolam sedimen.

Bangunan IPAL-TSI didesain dengan mengacu pada kebutuhan volume air buangan tambak untuk 12 petak TSI yang beroperasi dan air tambak yang terbuang maksimal $10 \mathrm{~cm}$ per hari. Berdasarkan asumsi tersebut, maka volume air buangan tambak yang masuk ke dalam IPAL mencapai $1.200 \mathrm{~m}^{3}$ setiap hari (Tabel 2), sementara kapasitas tampung IPAL mencapai 6.987 $\mathrm{m}^{3}$, berarti waktu tinggal air buangan di dalam IPAL mencapai sekitar 140 jam atau 5,8 hari. Air buangan tambak dengan waktu tinggal tersebut, diharapkan telah mengalami proses purifikasi sehingga memenuhi kriteria batas ambang yang dipersyaratkan untuk air buangan tambak. Waktu tinggal air buangan di IPAL dipengaruhi oleh volume tampung dan volume air buangan tambak. Volume air buangan semakin besar, maka waktu tinggal semakin singkat. Jumlah air buangan $1.200 \mathrm{~m}^{3}$ setiap hari setara dengan $5 \%$ dari total volume air tambak budidaya. Dengan waktu tinggal sekitar 5,8 hari; maka volume daya tampung IPAL minimal $30 \%$ dari total volume air tambak budidaya udang.

Tabel 1. Dimensi bangunan IPAL tambak superintensif

Table 1. Dimension of WTP building of superintensive pond

\begin{tabular}{lcccc}
\hline \multicolumn{1}{c}{$\begin{array}{c}\text { Kolam } \\
\text { Ponds }\end{array}$} & $\begin{array}{c}\text { Panjang } \\
\text { Length }(\mathbf{m})\end{array}$ & $\begin{array}{c}\text { Lebar } \\
\text { Wide }(\mathbf{m})\end{array}$ & $\begin{array}{c}\text { Kedalaman } \\
\text { Depth }(\mathbf{m})\end{array}$ & $\begin{array}{c}\text { Volume air } \\
\text { Water volume }\left(\mathbf{m}^{\mathbf{3}}\right)\end{array}$ \\
\hline Sedimentasi (Sedimentation) & 69 & 10 & 0.68 & 467 \\
Aerasi-1 (Aeration-1) & 69 & 10 & 1 & 692 \\
Aerasi-2 (Aeration-2) & 69 & 15 & 0.7 & 682 \\
Ekualisasi (Equalitation) & 69 & $40-48$ & 1.7 & 5,146 \\
\hline Total luas IPAL (Total WTP area) $\left(\mathrm{m}^{2}\right)$ & & & & 5,451 \\
Total volume IPAL (Total WTP volume) $\left(\mathrm{m}^{3}\right)$ & & & 6,987 \\
Volume air buangan ( $\mathrm{m}^{3} /$ hari) $/$ Effluent volume $\left(\mathrm{m}^{3} /\right.$ day) & & & & 1,200 \\
Waktu tinggal air buangan tambak dalam IPAL (hari) & & & & 5.82 \\
Retention time of effluent pond in the WTP (days) & & & & \\
\hline
\end{tabular}




\section{Karakteristik Air Buangan Tambak Superintensif}

Parameter kualitas air buangan yang memiliki nilai di atas ambang atas dari standar air buangan tambak yang diperkenankan yaitu TSS, BOT, TN, dan fosfat. Kandungan TSS air buangan TSI adalah 1.715,41 \pm $55,51 \mathrm{mg} / \mathrm{L}$ dan BOT 94,9580 $\pm 12,7142 \mathrm{mg} / \mathrm{L}$, untuk nilai TN dan $\mathrm{PO}_{4}-\mathrm{P}$ masing-masing 7,0759 $\pm 3,0504$ $\mathrm{mg} / \mathrm{L}$ dan 9,1900 \pm 6,2559 mg/L (Tabel 2). Standar air buangan tambak untuk kandungan TSS, BOT, TN, dan P04 masing-masing adalah $70 \mathrm{mg} / \mathrm{L}, 30 \mathrm{mg} / \mathrm{L}, 4 \mathrm{mg} / \mathrm{L}$, dan 0,4 mg/L sehingga keempat parameter tersebut telah melewati batas ambang yang diperkenankan. Sebelum dibuang ke lingkungan perairan, air buangan TSI harus dilakukan penanganan terlebih terdahulu agar tidak menjadi sumber cemaran yang potensial. Menurut Latt (2002), limbah tambak udang dapat berdampak terhadap kualitas perairan pesisir dan hidrologi, kehidupan organisme akuatik, mangrove dan vegetasi daratan.

\section{Kinerja IPAL Tambak Super Intensif}

Kolam sedimentasi memiliki peran penting dalam mengurangi beban limbah TSS dari 1.715,41 mg/L di inlet IPAL menurun menjadi $437,11 \mathrm{mg} / \mathrm{L}$ di outlet kolam sedimentasi (Tabel 3) dengan nilai efektivitas kolam sedimentasi mencapai $74,5 \%$ dan dikategorikan efisien. Castine et al. (2013), melaporkan kolam sedimentasi dapat menurunkan kandungan TSS sampai $60 \%$ Kolam ekualisasi juga memiliki peran cukup penting dalam menurunkan kandungan TSS dari 402,78 (outlet kolam aerasi) menjadi 10,14 mg/L (outlet ekualisasi) dengan nilai efektivitas kolam ekualisasi mencapai 97,5\% dan dikategorikan sangat efisien. Kolam ekualisasi juga cukup efisien mengurangi beban limbah TAN, nitrit, nitrat, Total N, dan fosfat. Semua parameter kunci menunjukkan penurunan yang signifikan dari kondisi di inlet dibandingkan outlet.
Keberadaan rumput laut Gracilaria sp. sebanyak 65 bentang @ 40 m dengan jumlah biomassa awal 300 $\mathrm{kg}$ yang ditanam di kolam ekualisasi, diduga memberikan kontribusi terhadap penyerapan unsur $\mathrm{N}$ dan $\mathrm{P}$, serta berfungsi sebagai perangkap bagi partikel koloid yang berada di air limbah. Produksi biomassa Gracillaria sp. setiap siklus pemeliharaan 40 hari dapat mencapai $1.253 \mathrm{~kg} / \mathrm{siklus}$. Beban limbah N dan $\mathrm{P}$ di kolam ekualisasi juga dimanfaatkan oleh fitoplankton yang berkembang dengan jumlah populasi berkisar 2.439-14.948 (7.473 \pm 4.128) sel/L $(n=7)$ dan berfungsi sebagai makanan alami bagi ikan mujair yang hidup di kolam IPAL. Dengan demikian, keberadaan rumput laut dan ikan mujair di dalam kolam ekualisasi memiliki peran ekologi yang penting dalam memperbaiki kualitas air limbah tambak superintensif. Pemanfaatan ikan nila, Oreochromis sp., dan lumut, Enteromorpha sp. yang dipelihara secara terintegrasi dengan udang vaname dengan sistem resirkulasi dapat menyerap beban limbah air buangan budidaya udang (Attasat et al., 2013).

Secara keseluruhan parameter kunci di IPAL-TSI menunjukkan kinerja yang baik dengan kisaran nilai efektivitas antara 53,1\%99,4\% (Tabel 4). Efektivitas IPAL untuk parameter BOT masih dalam kategori cukup efisien dengan nilai 53,1\% sementara parameter Nitrat masuk kategori efisien $(70,6 \%$, sedangkan parameter TSS $(99,4 \%)$, TAN $(92,7 \%)$, nitrit $(91,6 \%)$, Total N $(96,8 \%$, dan fosfat $(95,2 \%$ dinilai sangat efisien. Nilai parameter kunci kualitas air limbah TSI setelah melalui IPAL berada di bawah batas ambang yang dipersyaratkan dan dinilai layak untuk dibuang ke badan air, kecuali nilai BOT yang masih berada di atas standar effluent.

$\mathrm{BOD}_{5}$, menggambarkan banyaknya kebutuhan oksigen untuk mendekomposisi bahan organik dalam air buangan limbah TSI selama lima hari $\left(\mathrm{BOD}_{5}\right)$. Hasil pengukuran menunjukkan bahwa kandungan $\mathrm{BOD}_{5}$

Tabel 2. Kualitas air buangan tambak udang vaname superintensif $(n=10)$

Table 2. The quality of waste water of superintensif vaname shrimp $(n=10)$

\begin{tabular}{lcccc}
\hline $\begin{array}{c}\text { Parameter } \\
\text { Parameters }\end{array}$ & $\begin{array}{c}\text { Minimun } \\
\text { Minimum }\end{array}$ & $\begin{array}{c}\text { Maksimum } \\
\text { Maximum }\end{array}$ & $\begin{array}{c}\text { Rerata } \\
\text { Average }\end{array}$ & Sd \\
\hline TSS $(\mathrm{mg} / \mathrm{L})$ & $1,663.44$ & $1,773.89$ & $1,715.41$ & 55.51 \\
BOT/TOM $(\mathrm{mg} / \mathrm{L})$ & 80.2893 & 102.8138 & 94.9580 & 12.7142 \\
TAN $(\mathrm{mg} / \mathrm{L})$ & 3.5222 & 10.3333 & 6.91213 & 3.4056 \\
Nitrit/Nitrite $(\mathrm{mg} / \mathrm{L})$ & $\mathrm{nd}$ & 8.1167 & 2.8722 & 4.5486 \\
Nitrat/Nitrate $(\mathrm{mg} / \mathrm{L})$ & 0.5233 & 5.3318 & 2.3471 & 2.6060 \\
Total N $(\mathrm{mg} / \mathrm{L})$ & 3.8191 & 9.8662 & 7.0759 & 3.0504 \\
Fosfat/Phosphate $(\mathrm{mg} / \mathrm{L})$ & 1.9700 & 13.0000 & 9.1900 & 6.2559 \\
\hline
\end{tabular}

Catatan (Note): nd: not detected 
Tabel 3. Nilai parameter kunci di IPAL tambak superintensif $(n=10)$

Tabel 3. The values of the key parameters in the WTP of the superintensive pond $(n=10)$

\begin{tabular}{lccccc}
\hline \multicolumn{1}{c}{$\begin{array}{c}\text { Parameter } \\
\text { Parameters }\end{array}$} & $\begin{array}{c}\text { Inlet IPAL } \\
\text { WTP inlet }\end{array}$ & $\begin{array}{c}\text { Outlet kolam } \\
\text { sedimentasi } \\
\text { Sedimentation } \\
\text { pond outlet }\end{array}$ & $\begin{array}{c}\text { Outlet kolam } \\
\text { aerasi } \\
\text { Aeration } \\
\text { pond outlet }\end{array}$ & $\begin{array}{c}\text { Outlet kolam } \\
\text { ekualisasi } \\
\text { Equalization } \\
\text { pond outlet }\end{array}$ & $\begin{array}{c}\text { Standard } \\
\text { effluent }\end{array}$ \\
\hline TSS $(\mathrm{mg} / \mathrm{L})$ & $1,715.41$ & 437.11 & 402.78 & 10.14 & $<70$ \\
BOT $(\mathrm{TOM})(\mathrm{mg} / \mathrm{L})$ & 94.9580 & 65.3425 & 63.1178 & 44.5360 & $<30$ \\
TAN $(\mathrm{mg} / \mathrm{L})$ & 6.91213 & 2.4194 & 2.1000 & 0.5013 & \\
Nitrit $($ Nitrite) $(\mathrm{mg} / \mathrm{L})$ & 2.8722 & 2.2801 & 1.3528 & 0.2412 & \\
Nitrat $($ Nitrate) $(\mathrm{mg} / \mathrm{L})$ & 2.3471 & 2.1288 & 1.9106 & 0.6891 & \\
Total N (mg/L) & 7.0759 & 2.9337 & 2.8512 & 0.2257 & $<4$ \\
Fosfat (Phosphate) $(\mathrm{mg} / \mathrm{L})$ & 9.1900 & 3.6944 & 2.0917 & 0.4448 & $<0.4$ \\
BOD $_{5}(\mathrm{mg} / \mathrm{L})$ & 19.80 & 12.83 & 10.74 & 7.02 & $<20$ \\
\hline
\end{tabular}

Sumber (Source):*) Ministry of Natural Resources and Environment (2007)

Tabel 4. Efektfitas kinerja IPAL tambak superintensif

Table 4. The effectiveness of WTP performance of superintensive ponds

\begin{tabular}{|c|c|c|c|c|c|}
\hline \multirow{2}{*}{$\begin{array}{l}\text { Parameter } \\
\text { Parameters }\end{array}$} & \multicolumn{4}{|c|}{ Efektivitas kolam (Pond effectiveness) ( $\%$ ) } & \multirow{2}{*}{$\begin{array}{l}\text { Efisiensi IPAL } \\
\text { Efficiency of WTP }\end{array}$} \\
\hline & $\begin{array}{l}\text { Sedimentasi } \\
\text { Sedimentation }\end{array}$ & $\begin{array}{c}\text { Aerasi } \\
\text { Aeration }\end{array}$ & $\begin{array}{l}\text { Ekualisasi } \\
\text { Equalization }\end{array}$ & $\begin{array}{l}\text { IPAL } \\
\text { WTP }\end{array}$ & \\
\hline TSS (mg/L) & 74.5 & 7.9 & 97.48 & 99.4 & Sangat efisien (Very efficient) \\
\hline ВОТ/TOM (mg/L) & 31.2 & 3.4 & 29.44 & 53.1 & Cukup efisien (Quite efficient) \\
\hline TAN (mg/L) & 65.0 & 13.2 & 76.13 & 92.7 & Sangat efisien (Very efficient) \\
\hline Nitrit/Nitrite (mg/L) & 20.6 & 40.7 & 82.17 & 91.6 & Sangat efisien (Very efficient) \\
\hline Nitrat/Nitrate (mg/L) & 9.3 & 10.2 & 63.93 & 70.6 & Efisien (Efficient ) \\
\hline Total N (mg/L) & 58.5 & 2.8 & 92.08 & 96.8 & Sangat efisien (Very efficient) \\
\hline Fosfat/Phosphate (mg/L) & 59.8 & 43.4 & 78.74 & 95.2 & Sangat efisien (Very efficient) \\
\hline $\mathrm{BOD}_{5}(\mathrm{mg} / \mathrm{L})$ & 34.34 & 16.29 & 34.64 & 64.1 & Efisien (Efficient ) \\
\hline
\end{tabular}

sebesar 19,54 mg/L di inlet IPAL menurun menjadi 7,02 $\mathrm{mg} / \mathrm{L}$ di outlet IPAL (Tabel 4 ) dengan tingkat efektivitas IPAL mencapai 64,07\%(Tabel 4).

Kandungan bakteri TPC di petak ekualisasi berkisar 3.000-107.000 (36.316 $\pm 31.342 \mathrm{cfu} / \mathrm{mL})$ dan TBV antara 724-2.540 (781 $\pm 1.769 \mathrm{cfu} / \mathrm{mL})$. Keberadaan bakteri di IPAL berasal dari buangan air limbah petak pemeliharaan udang. Perlakuan penambahan bakteri pengurai terhadap air limbah di IPAL perlu dipertimbangkan mengingat jumlah bakteri TPC telah mencapai $10^{4} \mathrm{cfu} / \mathrm{mL}$. Oleh karena itu, perbaikan rasio $\mathrm{C} / \mathrm{N}$ dengan penambahan sumber karbon diduga dapat memacu proses nitrifikasi sehingga nitrat yang terbentuk akan cepat dimanfaatkan oleh fitoplankton yang pada akhirnya dapat menurunkan beban limbah $\mathrm{N}$ berada pada batas ambang yang dipersyaratkan.
Hasil uji hayati menunjukkan bahwa organisme uji berupa benur vaname PL-10, nener $(3,13 \pm 1,38 \mathrm{~g} /$ ekor), benih nila $(0,25 \pm 0,03$ g/ekor), dan benih mujair $(0,96 \pm 0,15$ g/ekor) masih dapat hidup normal pada media air buangan yang berasal dari kolam ekualisasi dengan sintasan $100 \%$ selama pemaparan 96 jam (Fahrur et al., 2016). Hal ini dibuktikan di lapangan dengan tumbuh kembangnya ikan mujair, udang vaname, dan jenis ikan lain, serta rumput laut sebagai hasil samping IPAL. Dengan demikian, air buangan tambak superintensif yang telah melewati IPAL dapat dinyatakan aman dibuang ke perairan dan layak bagi kehidupan organisme perairan lainnya.

Gracilaria sp. terbukti dapat mengasimilasi nitrogen terlarut yang ada di dalam air limbah budidaya udang sebanyak 6,5\%(Troell et al., 1999). Dalam skala 
laboratorium, G. verrucosa mampu memindahkan sebanyak 94,5\%nitrit; 91,4\%nitrat; 99,3\%amonia; dan $100 \%$ fosfat dari air buangan budidaya selama periode 20 hari. Rumput laut G. gigas dan G. verrucosa yang dipelihara di petak ekualisasi menunjukkan kualitas yang baik dengan kadar protein antara 13,91\%15,32\% dan kandungan agar 14,11\%17,00\%(Tabel 5). Kandungan agar pada rumput laut yang dipelihara di IPAL lebih tinggi jika dibandingkan dengan Gracilaria sp. yang dipelihara di tambak $(9,62 \%$, hasil seleksi klon $(8,70 \%)$ maupun hasil kultur jaringan $(12,38 \%$ (Mulyaningrum et al., 2014). Pertumbuhan G. verrucosa di IPAL mencapai 4,21\% /hari lebih tinggi dibandingkan dengan hasil penelitian Trawanda et al. (2014) terhadap G. verrucosa hasil seleksi (1,55\%/hari) dan kultur jaringan (1,41\%hari). Rumput laut cukup potensial untuk menyerap nutrien (Songsangjinda, 2004; Devi \& Gowri, 2007) sehingga dapat dimanfaatkan dalam budidaya terintegrasi dengan udang dan menjadi bagian dari perlakuan terhadap air buangan tambak.

Dampak negatif dari kegiatan budidaya ke lingkungan perairan telah terjadi di Thailand (Tookwinas, 1988), Vietnam (Anh et al., 2010), Cina (Cao et al., 2007), dan pengaduan masyarakat akibat dampak lingkungan yang bersumber dari aktivitas tambak udang di Indonesia terjadi di Buleleng (Bali), Tulungagung (Jawa Timur), Bantul (Yogyakarta), Bima (Nusa Tenggara Barat), Bengkulu, Pesawaran (Lampung) (Wibowo, 2017), meskipun keberadaannya hanya sebagian kecil dari pencemaran yang bersumber dari kegiatan di daratan. Perencanaan yang benar dal am memanfaatkan limbah akuakultur untuk mengurangi masalah pencemaran perairan dapat dilakukan dengan mengambil manfaat dari nutrien yang berada di limbah tersebut melalui pengembangan sistem budidaya terpadu dengan komoditas yang berada pada tropik level yang lebih rendah seperti rumput laut, ikan herbivor, dan kekerangan, serta pemanfaatan kembali sebagai air baku pada sistem budidaya resirkulasi. Sedimen TSI yang terbentuk terbukti dapat dimanfaatkan sebagai bahan baku pupuk organik (Suwoyo et al., 2016a) dan dapat diaplikasikan untuk pemupukan tambak udang dan ikan ekstensif (Suw oyo et al., 2016b), bahkan di Thailand telah dimanfaatkan sebagai pupuk organik komersial (Latt, 2002). Lumpur yang dihasilkan dari tambak udang dapat juga digunakan sebagai media untuk menghasilkan tepung bioflok (Neto et al., 2015).

Berdasarkan evaluasi desain dan kinerja IPAL tambak superintensif, maka diketahui IPAL-TSI di Instalasi Tambak Perco baan Punaga dapat diaplikasikan sebagai piranti unit pengolah air buangan TSI dalam upaya meminimalkan dampak negatif bagi beroperasinya TSI di kawasan pesisir. Informasi rasio volume IPAL dan total volume air media budidaya minimal 30:70 dengan waktu tinggal limbah di IPAL minimal lima hari, dapat dijadikan acuan bagi penyusunan bahan kebijakan dalam pembuatan regulasi pengembangan TSI yang keberlanjutan. Strategi pengembangan budidaya udang secara berkelanjutan diarahkan pada upaya perlindungan manfaat lingkungan melalui pengaturan padat penebaran dan beban limbah sesuai daya dukung lingkungan.

\section{KESIMPULAN DAN SARAN}

\section{Kesimpulan}

IPAL tambak superintensif di ITP Punaga mampu menopang beroperasinya 12 unit tambak superintensif @ $1.000 \mathrm{~m}^{2}$ dengan asumsi jumlah volume beban

Tabel 5. Komposisi proksimat rumput laut yang dipelihara di petak penampungan IPAL

Table 5. Proximate composition of seaweed cultivated in the equalization pond of WTP

\begin{tabular}{lcc}
\hline \multicolumn{1}{c}{ Parameter (Parameters) } & G. gigas & G. verrucosa \\
\hline Kadar abu (Ash content) (\%) & 49.39 & 52.74 \\
Kadar air (M oisture) (\%) & 2.48 & 3.11 \\
Lemak kasar (Crude fat) (\%) & 0.23 & 0.25 \\
Protein kasar (Crude protein) (\%) & 15.32 & 13.91 \\
Serat kasar (Crude fibre) (\%) & 14.32 & 11.77 \\
Total N (Total N) (\%) & 2.45 & 2.23 \\
Kandungan agar (Agar content) (\%) & 17.00 & 14.11 \\
Pertumbuhan (\%hari) / Daily growth (\%day) & nd & $4.21 \pm 0.87$ \\
\hline
\end{tabular}

Keterangan (Note): nd: tidak ada data (no data) 
limbah sebesar $1.200 \mathrm{~m}^{3} /$ hari (5\% dari total volume media air tambak) dengan laju alir $20 \mathrm{~m}^{3} /$ menit dan waktu tinggal limbah di dalam IPAL minimal lima hari. Rasio volume IPAL dengan volume air media budidaya tambak superintensif minimal 30:70. Efektivitas kinerja IPAL untuk parameter kunci air limbah (TSS, total N, fosfat) dikategorikan sangat efisien. Sementara $\mathrm{BOD}_{5}$ dikategorikan efisien dan BOT cukup efisien. Kinerja IPAL tambak superintensif menghasilkan kualitas air limbah yang memenuhi persyaratan standar air buangan limbah tambak sehingga layak dibuang ke badan air penerima beban limbah.

\section{Saran}

Pemeliharaan kolam sedimentasi perlu dilakukan secara berkala dengan memindahkan endapan sedimen menggunakan pompa lumpur. Aplikasi alat bantu aerasi dasar kolam perlu diuji pada kolam aerasi di IPAL untuk mempercepat proses pengudaraan dan pelarutan oksigen terlarut dalam menopang proses dekomposisi bahan organik air limbah. Untuk meningkatkan kinerja petak aerasi-2, maka dapat ditambahkan substrat berupa batu gunung, kerikil, kulit kerang, pecahan karang, dan bioball, berfungsi memacu proses nitrifikasi.

\section{UCAPAN TERIMA KASIH}

Terima kasih disampaikan kepada Sdr. Sapar, Ilham, Hamzah, Ahmadirrahman, Eko Apriliyanto, dan Fuad Ahmad sebagai teknisi lapangan dan analis di laboratorium air, nutrisi, dan patologi yang telah membantu kelancaraan penelitian ini. Penelitian ini dibiayai oleh APBN melalui DIPA 2016 Balai Penelitian dan Pengembangan Budidaya Air Payau, Maros

\section{DAFTAR ACUAN}

Anh, P.T., Kroeze, C., Bush, S.R., \& Mol, A.P.J. (2010). Water pollution by intensive brackishwater shrimp farming in south-east Vietnam: Causes and options for control. Aquaculture Water Management, 97, 872-882.

Atjo, H. (2014). Budidaya udang vaname supra intensif Indonesia. Shrimp Club Indonesia Sulawesi. $4 \mathrm{hlm}$.

Attasat, S., Wanichpongpan, P., \& Ruenglertpanyakul, W. (2013). Design of integrated aquaculture of Pacific white shrimp, tilapia and green mussel. Journal of Sustainable Energy \& Environment, 4, 9-14.

Cao, L., Wang, W., Yang, Y., Yang, C., Yuan, Z., Xiong, S., \& Diana, J. (2007). Environmental impact of aquaculture and countermeasures to aquaculture pollution in China. Env. Sci. Pollut. Res., 14(7), 452-462.
Castine, S.A., McKinnon, A.D., Paul, N.A., Trott, L.A., $\&$ de Nys, R. (2013). Wastewater treatment for land-based aquaculture: improvements and valueadding alternatives in model systems from Australia. Aquaculture Environment Interactions, 4, 285300. doi: 10.3354/aei00088.

Crab, R., Avnimelech, Y., Defoirdt, T., Bossier, P., \& Verstraete, W. (2007). Nitrogen removal techniques in aquaculture for a sustainable production. Aquaculture, 270, 1-14. doi: 10.1016/ j.aquaculture.2007.05.006.

de Azevedo, R.V., Tonini, W.C.T., dos Santos, M.J.M., \& Braga, L.G.T. (2015). Biofiltration, growth and body composition of oyster Crassostrea rhizophore in effluents from shrimp Litopenaeus vannamei. Revista Ciencia Agronomica, 46(1), 193-203.

Devi, R.P. \& Gowri, V.S. (2007). Biological treatment of aquaculture discharge waters by seaweeds. J. of Industrial Pollution Control, 23(1), 135-140.

Divya, M., Aanand, S., Srinivasan, A., \& Ahilan, B. (2015). Bioremediation-An eco-friendly tool for efflunet treatment: A Review. International Journal of Applied Research, 1(12), 530-537.

Fahrur, M., Undu, M.C., \& Syah, R. (2016). Performa instalasi pengolah air limbah tambak udang vaname superintensif. Prosiding Forum Inovasi Teknologi Akuakultur, hlm. 285-293.

Fahrur, M., Makmur, \& Undu, M.C. (2015). Karakteristik air buangan limbah budidaya udang vaname superintensif. Prosiding Forum Inovasi Teknologi Akuakultur, hlm. 1015-1026.

Hochheimer, J.N. (2003). Aquacultural effluent: Overview of EPA'S guidelines and standards. In Summerfelt, R.C. \& Clayton, R.D. (Eds). Proceedings of The North Central Regional Aquaculture Center, p. 20-26.

Hongsheng, Y., Ying, L., Kui, Y., \& Shilin, L. (2008). Design and performance of superintensive shrimp culture system. Institute of Oseanology, Chinese Academy of Sciences.

Jegatheesan, V., Zeng, C., Manicom, C., \& Steicke, C. (2006). Technological advances in aquaculture farms for minimal effluent discharge to oceans. Journal of Cleanner Production, p. 1-10. doi: 10.1016/ j.jclepro.2006.07.043.

Jones, A.B., Denisson, W.C., \& Preson, N.P. (2011). Integrated treatment of shrimp effluent by sedimentation, oyster filtration and macroalgal absorption: a laboratory scale study. Aquaculture, 193(12), 155-178.

Krummenauer, D., Samocha, T., Poersch, L., Lara, G., $\&$ Wasielesky, Jr.W. (2014). The reuse of water on the culture of Pacific white shrimp Litopenaeus 
vannamei, in BFT system. Journal of the World Aquaculture Society, 45(1), February 2014. doi: 10.1111/ jwas.12093.

Latt, U.W. (2002). Shrimp pond waste management. Aquaculture Asia, 3, 11-16.

Ministry of Natural Resources and Environment. (2007). Effluent Standar for Brackish Aquaculture. Published in the Royal Goverment Gazette, Vol. 124 Special Part 84D, date July 13, B.E. 2550.

Mulyaningrum, S.R.H., Daud, R., \& Suryati, E. (2014). Performa pertumbuhan dan kandungan agar bibit rumput laut Gracilaria sp. dari sumber berbeda yang dipelihara dengan sistem tebar di hapa. Prosiding Seminar Nasional Tahunan XI Hasil Penelitian Perikanan dan Kelautan. Jurusan Perikanan Fakultas Pertanian UGM, Jilid 1, 299-305.

Neto, H.S., Santaella, S.T., \& Nunes, A.J.P. (2015). Bioavailability of crude protein and lipid from biofloc meals produced in an activated sludge systems for white shrimp, Litopenaeus vannamei. R. Bras.Zootec., 44(8), 269-275.

Preston, N.P., Jackson, C.J., Thompson, P., Austin, M., Burford, M.A., \& Rothlisberg, P. (2001). Prawn farm effluent: composition, origin and treatment. Project No. 95/162. Fisheries Reaserach and Development Corporation, Cleveland, $\mathrm{OH}$.

Rahardjo, S., Suprihatin, Indrasti, N.S., Riani, E., Supriyadi, \& Hardanu, W. (2015). Lahan basah buatan sebagai media pengolahan air limbah budidaya udang vaname (Litopenaeus vannamei) bersalinitas rendah. J. Manusia dan Lingkungan, 22(2), 201-210.

Songsangjinda, P. (2004). Integrated physical dan biological technologies for water recycling in shrimp farms. In Promotion of mangrove-friendly shrimp aquaculture in Southeast Asia (p. 36-49). Tigbauan, Iloilo, Philippines: Aquaculture Department, Southeast Asian Fisheries Development Center.

Suwoyo, H.S., Fahrur, M., \& Syah, R. (2016a). Potensi limbah padat tambak udang superintensif sebagai bahan baku pupuk organik. Dalam Yasir, I., Tresnati, J., Aslamiyah, S., Umar, M.T., \& Firman (Eds.). Prosiding Simposium Nasional Kelautan dan Perikanan III, Universitas Hasanuddin. Makassar, hlm. 406-415.

Suwoyo, H.S., Fahrur, M., Makmur, \& Syah, R. (2016b). Pemanfaatan limbah tambak udang superintensif sebagai pupuk organik untuk pertumbuhan biomassa klekap dan nener bandeng. Media Akuakultur, 11(2), 97-110.
Suwoyo, H.S., Tahe, S., \& Fahrur, M. (2015). Karakterisasi limbah sedimen tambak udang vaname (Litopenaeus vannamei) superintensif dengan kepadatan berbeda. Prosiding Forum Inovasi Teknologi Akuakultur 2015. Pusat Penelitian dan Pengembangan Perikanan Budidaya. Jakarta, hlm. 901-913.

Syah, R., Makmur, \& Fahrur, M. (2017). Budidaya udang vaname dengan padat penebaran tinggi. Media Akuakultur, 12(1), 19-26.

Syah, R., Makmur, \& Undu, M.C. (2014). Estimasi beban limbah nutrien pakan dan daya dukung kawasan pesisir untuk tambak udang vaname superintensif. Jurnal Riset Akuakultur, 9(3), 439-448.

Syah, R., Suwoyo, H.S., Undu, M.C., \& Makmur (2006). Pendugaan nutrient budget tambak intensif udang Litopenaeus vannamei. Jurnal Riset Akuakultur, 1(2), 181-202.

Tchobanoglous, G., Burton, F.L., Metcalf, \& Eddy (1991). Wastewater engineering: treatment, disposal, and reuse. 3rd Ed. New York: McGraw-Hill, $1334 \mathrm{pp}$.

Teichert-Coddington, D., Martinez, D., \& Ramirez, R. (1995). Characterization of shrimp farm effluents in Honduras and chemical budget of selected nutrients. Thirteenth Annual Report. 1 September 1994 to 31 August 1995. Pond Dynamics/Aquaculture Collaborative Research Support Program. Oregon State University, Corvallis, Oregon, USA, $15 \mathrm{pp}$.

Tookwinas, S. (1988). The environmental impact of marine shrimp farming effluents and carrying capacity estimation at Kung Krabaen bay, Eastern Thailand. Asian Fisheries Science, 11, 303-316.

Trawanda, S.A., Rejeki, S., \& Ariyati, R.W. (2014). Kuantitas dan kualitas rumput laut Gracilaria sp. bibit hasil seleksi dan kultur jaringan dengan budidaya metode long line di tambak. Journal of Aquaculture Management and Technology, 3(2), 150158. Online: http://ejournal-sl.undip.ac.id/index.php/ jamt.

Troell, M., Ronnback, P., Halling, C., Kautsky, N., \& Buschmann, A. (1999). Ecological engineering in aquaculture: use of seaweeds for removing nutrients from intensive mariculture. Journal of Applied Phycology, 11, 89-97.

Wibowo, A.H. (2017). Kebijakan pengendalian limbah tambak dengan IPAL communal. Direktorat Kawasan \& Kesehatan Ikan. Direktorat Jenderal Perikanan Budidaya, Kementerian Kelautan dan Perikanan. Jakarta, $17 \mathrm{hlm}$. 